\title{
Muslim Education During the Period of Political Turmoil, 1921-1935: The Case of Colonial Bengal
}

\author{
Nilanjana Paul \\ West Virginia University, Morgantown, USA
}

\begin{abstract}
This paper discusses the state of Muslim education in colonial Bengal during the crucial years of 1920s and 1930s. It evaluates the impact of some of the post war reforms introduced by the colonial government to improve Muslim education, and shows how these reforms influenced the progress of the community. It also analyzes how the relationship between Hindus and Muslims gradually deteriorated as a result of these educational reforms. This paper provides a comprehensive overview of the educational reforms introduced during the period of intense political and financial crises.
\end{abstract}

Keywords: Muslim education, Hindus and Muslims, educational reforms

\section{Introduction}

After the Partition of Bengal (1905) and Morley Minto reforms (1909), the British in India considerably expanded imperial and legislative councils to include Muslim landlords and professionals. They mostly included Muslim elites in these councils. Shortly after, the qualifications for Muslim voters were lowered, and the reforms established separate electorates in several provinces. Historians have argued that British used this method of separate electorates to encourage communal separatism. P. Hardy (1983) argued that although Indians were given certain concessions, British retained the major executive responsibilities. Separate electorates carved out a particular role for Muslims in the Indian society, which got complicated after the war. However, post-war reforms, including the Lucknow Pact of 1916, and the Montagu Chelmsford reforms of 1918 reduced Muslims to the status of political minority. This uncertainty forced Muslims to demand separate educational institutions for the advancement of the community. Unfortunately, education policies were constantly influenced by the political events of the 1920s and 1930s. These incidents had an adverse influence on the progress of education, as the government reduced financial support to these institutions.

This paper examines the state of Muslim education in colonial Bengal in the 1920s and 1930s. It explores the impact of legislative acts on education. For example, the Montagu-Chelmsford reforms of 1918 further supported the idea of separate educational institutions and electorates for Muslims. This resulted in the establishment of the Dhaka University in 1921. The Dhaka University is used here as a case study to measure the progress made by the Muslims of East Bengal after the introduction of diarchy (explained later) in 1918. At the same time, legislative and educational reforms intensified the demand for Muslim representation in school

Nilanjana Paul, Ph.D. candidate, Department of History, West Virginia University.

Correspondence concerning this article should be addressed to 777 Chestnut Ridge Road Apt\#205 Morgantown WV 26505. E-mail: npaul1@mix.wvu.edu. 
committees, university senates, and municipalities. Muslim members of the Bengal Legislative Council demanded special provision in the budget for their community and reservation of seats for Muslims in educational institutions and government jobs. The effort to include Indians in the development of the country aggravated the social situation of the province, as there were limited jobs and educational institutions.

This paper also analyzes the impact of historical events, such as the Khilafat (1919), Non-cooperation (1919-1922), and Civil Disobedience movements (1930-1932), on colonial education policies. During the interwar years, the number of Muslim students in professional and arts colleges decreased. Reservation of seats did not improve the educational situation of the community, and Muslims considered Hindus to be their competitors and enemies. The role played by Muslim leaders in the implementation of the Bengal Rural Primary Education Bill of 1930 is also reviewed in this context.

Based on careful reading of primary and secondary sources, I argue that the effort to introduce responsible government in the provinces only intensified communal consciousness. Nation-building institutions, such as the education system, did not adequately improve the social status of Muslims. The Bengal Education Department struggled throughout the colonial period to develop policies that helped the masses. Limited resources, discrimination in education, and employment followed by the failure to implement policies turned the Bengali intelligentsia against colonial rule. This failure forced Muslims to believe that separate educational institutions could only improve their social status, and strengthened the idea that Muslim aspirations were different from those of Hindus. In other words, educational reforms escalated Muslim separatism during the 1920s and 1930s, which prepared the ground for the emergence of separate nations in 1947.

\section{The Last Stage of Hindu Muslim Unity: From the End of World War I to the Bengal Pact of 1923 (1916-1923)}

\section{The Impact of the Montagu-Chelmsford Reforms on the Progress of Muslim Education}

This section explores the status of Muslim education after World War I. After the war, there was definite shift in the British Indian policy. In order to pacify the Indians, the colonial government allowed the natives to participate in the development of the country. The Montagu-Chelmsford reforms started the system of diarchy, where elected ministers of the provincial legislatures independently looked after departments, such as agriculture, education, and health. This section shows that although Indians were allowed to participate in the decision-making process, major education policies were formulated and controlled by the government. These policies eventually prepared the ground for the rise of communalism in colonial Bengal.

During World War I, the Indian revolutionaries organized several conspiracies to overthrow the colonial government. The government responded to such conspiracies by introducing the Defense Act of 1915, which detained suspects without trials. However, leaders such as Mahatma Gandhi and Balgangadhar Tilak, supported the British during World War I. They hoped that colonial rulers would introduce major political reforms in return for such loyalty. This loyalty to a certain extent produced effective results, as the colonial government introduced self-governing institutions immediately after World War I. Apparently, the government wanted Indians to participate in the process of developing the country. This shift in the British policy influenced the progress of education. The government introduced the reformed madrassah (religious schools for Muslims) system immediately after the war in 1915 to improve Muslim education.

Muslim intellectuals, such as Munshi Imdad Ali and Khan Bahadur Ahsanullah, supported the colonial policy of reforming madrassahs. They believed that madrassahs should introduce English, as this helped 
Muslims to progress. Also, just a few Muslim students wanted to pursue the orthodox course of education. Even maulvis (Muslim religious teachers) from northern India, such as Jame-ul-uloom, suggested that the reformed madrassah system improved the social condition of the community. It established madrassahs in rural areas and introduced a secular curriculum that helped Muslims to secure government jobs.

Although reforms were introduced after the war, the government continued to reduce funding for education. The government decided that provincial revenue would bear the expenses of the government and non-government madrassahs of the province. Small stipends were given to Muslim students from the Mohsin Endowment Fund, but it was insufficient in comparison to the total Muslim population of the province. Posts of five assistant inspectors for Muslim education were abolished, and grants for maktabs (primary schools for Muslims, which mostly taught the Koran) and madrassahs were decreased by 7,500 and 220,000 rupees respectively. The number of Muslim students declined at the Dhaka Madrassah between 1918 and 1921 from 425 to 315. Similarly, at the Chittagong Madrassah, the number declined from 190 to 164. Lack of government assistance, absence of Muslim teachers, and poverty affected the enrollment of Muslim students in middle and high schools. Muslim students in middle schools decreased from 24,857 in 1916 to 15,401 in 1922. A similar situation was noticed in high schools, where the number of Muslims decreased from 19,916 in 1916 to 14,168 in 1922.

This decrease in financial aid was condemned by educationists, such as M. Azizul Huque. Muslims were forced to discontinue their education, and schools, colleges, and universities preferred Hindus over Muslims. In 1917, Calcutta had 1,700 Muslim undergraduates, of which only 125 were able to study at the Presidency College. The rest were mostly admitted to City, Ripon, or Bangabashi colleges. In these colleges, Muslim students were unable to pursue education in Persian, Arabic, or History. Out of the 800 students admitted in medical colleges, only 10 were Muslims. There were no Muslim students in the Shibpur Engineering College, as Muslims were unsure of their future and afraid of high fees. A few charitable funds helped Muslim students to pursue higher education. The Calcutta University did not elect Muslims as fellows of the university. Hindus only had the right to vote, and qualified Muslims were not included in the Syndicate of the Calcutta University. Huque (1917) criticized the Calcutta University for not providing equal opportunities to students from different religions. Muslims were denied government jobs because there were only a few Muslim representatives in the administration or on the managing boards of educational institutions. Huque was skeptical of Lord Hardinge's proposal to establish a new university for Muslims at Dhaka, as he felt that this would only complicate the political environment.

However, Huque (1917) also recognized the limitations of the government and urged the Muslim community to solve their own problems instead of depending on the government. He wanted Muslims to change their attitudes towards education in order to progress and compete with Hindus. Huque did not have much faith in the government, but advised Muslims to look beyond their religious goals and make use of the limited opportunities offered by the colonial government. He believed that the community should progress organically instead of depending on the government.

Following the recommendations of Huque, Muslims were eager to learn English. Maulvi Abu Muhammad Abdul Huq of Delhi (1915) suggested that English had to be introduced as a compulsory subject in the madrassahs and that Islam did not oppose the study of other languages. Unfortunately, there was no proper financial support from the government. Along with madrassahs, colleges also suffered from financial problems. For example, during the war, the government withdrew support from Brojo Mohan College of East Bengal, as 
they were dissatisfied with the discipline of the college. This decrease in financial assistance affected the progress of education among Muslims of East Bengal. Although Muslims were interested in English education, the absence of a proper educational infrastructure prevented the advancement of the community.

After the war, the Montagu-Chelmsford reforms of 1918, the Government of India Act of 1919, and the political movements that were led by Gandhi (discussed in the next section) shaped the future of the Indian national movement in the 20th century. The Montagu-Chelmsford reforms took the final shape under the Government of India Act of 1919. The act of 1919 introduced a bicameral system at the center, consisting of the Council of State and a Legislative Assembly. Based on this system, certain departments, such as education and agriculture, were transferred to the elected Indian ministers of the provincial legislatures. At the same time, vital departments, such as finance and revenue, were controlled by the government. The act encouraged the establishment of separate schools for Muslims and considerably extended electorates and communal representation.

However, the reforms proposed by the Government of India Act of 1919 were not free from criticisms. Abdul Karim, an honorary fellow of the Calcutta University, at the annual session of the Bengal Provincial Muslim League in 1920, suggested that the reforms did not improve the overall condition of Muslims (Karim, 1925). The system of separate electorates and schools were unsuitable for the community. There was a dearth of qualified Muslims who could represent the community in local councils and also on the managing committees of middle and high schools. Muslim schools did not have Muslim teachers, and textbooks were unsuitable for Muslim students. Inadequate scholarships, high fees, absence of high schools in Muslim localities, and the non-cooperation movement hindered the advancement of the community. Karim (1925) wanted to extend mass education and desired the establishment of another teaching university. Although the Education Department was transferred to the elected ministers, the concern remained the same over the next few years. There was a huge demand for financial assistance from the government.

Huque and Karim worked for the colonial government, yet they vehemently opposed the proposal to establish a separate university for Muslims at Dhaka. According to them, the proposed university would increase the financial burden of the government (Huque, 1917; Karim, 1925). Despite all the criticisms, Dhaka University was established in 1921. It was established to provide instruction in Islamic studies to the Muslims of East Bengal. It also provided instruction in English, Bengali, Mathematics, Geography, Physics, and classical languages. The university included the Dhaka, Jagannath Intermediate, Muhammadan, and Salimullah colleges, along with a college for women and a technical institute. The colonial rulers wanted to build a residential university at Dhaka, which encouraged research and originality of thoughts. Unlike the Calcutta University, which included students from several colleges, the students of the Dhaka University were required to reside in halls or hostels following a strict code of discipline prescribed by the university. Students of either sex were admitted without any discrimination on the basis of race, creed, or class. The university also granted degrees and awarded fellowships. Religious instruction was an important part of the curriculum. Students were admitted after passing the intermediate examination, and the university offered instruction in arts and sciences. Sir Philip Hartog, the first vice-chancellor of the Dhaka University, wanted to include more Muslim students in order to improve the educational situation of the community. He requested the elected ministers for more grants.

The annual reports of the Dhaka University from 1922 to 1924 showed that students were keen on attending the new university, which provided new methods of intellectual training and unparalleled facilities for 
athletics. There were suggestions to improve the library and appoint a full-time professor for the Arabic and Islamic Studies Department. The number of students at the university increased from 1,105 to 1,330 between 1922 and 1923. Similarly, the number of medical and research students increased from 121 to 139 and from 10 to 19 respectively between 1923 and 1924. The Dhaka University officials notified that there was a decrease in the number of students studying humanities, whereas there was an increase in the number of students pursuing science and law. The university provided several opportunities for publication of research. Students had to reside in halls, and there was a separate hall for Muslim students. The Muslim Hall offered Koran classes, and the halls played an important role in the overall development of students. They were required to participate in debates, sports, and social service. For example, the Jagannath Hall of the Dhaka University required students to attend all the lectures, and they were not allowed to miss more than three classes. Each hall had a social service league, which provided poor villagers with education during the term. The government was confident that this residential form of education would benefit students.

Unfortunately, the colonial government reduced financial aid to the Dhaka University immediately after its establishment in 1922. The Bengal Retrenchment Committee, established in 1921 to monitor the savings of the colonial government in the province, decided to reduce the financial aid in order to maintain a strict budget. The Dhaka Herald and A Voice from East Bengal in 1922 criticized the government and the retrenchment committee for reducing a grant of five lakh rupees to one lakh without proper inspection of the university. The progress of applied sciences and technical courses was affected by this reduction in financial assistance. The expenditure on books and libraries decreased, and professors were not appointed to the Arabic and Islamic Studies Department. The university had no other sources of funding except for government assistance and the retrenchment committee suggested that students' fees had to be increased. Abdul Karim only predicted this situation in 1920. The residential university was unaffordable for a vast majority of poor Muslims, and the decrease in grant money affected the progress of education. A section of the Muslim population was educated, as they were the only ones who could pay the increased fees of the Dhaka University.

Newspaper reports also indicated that the Dhaka University did not improve the educational condition of Muslims. There was mass illiteracy, and this aggravated the political situation of the province, as Muslims blamed the colonial government and powerful Hindus for their impoverishment. The colonial government did not appoint Muslim officers to different posts within the Dhaka University. For example, in the Economics Department, a Hindu and a Muslim candidate with the same qualifications were interviewed, and the Hindu candidate was appointed to the post. This was due to the fact that the Hindu candidate had six months' work experience, whereas the Muslim candidate had five months' work experience. Despite several recommendations that the Muslim candidate be appointed, the committee selected the Hindu candidate. Even the vice-chancellor of the university was unable to change the unanimous decision of the committee. A similar incident took place in the law department where a qualified Muslim lawyer was not appointed as the Chair of the department. There were not just financial crises, but also discrimination in the appointment of Muslims as officers and teachers. The power of nominating Muslims as university fellows was never properly exercised by the colonial government. The government in practice preferred Hindus over Muslims, and so the reforms introduced failed to generate desired results. Unfortunately, these grievances increased over the next two decades leading to communal tension and eventually riots.

The number of educated Muslims increased from the 19th to the 20th century, but the impact was never felt by the entire community. Even after the establishment of the Dhaka University where preference was given 
to Muslims, Hindus dominated academia and the administration of the university. The colonial government favored Hindus over Muslims for various positions. Qualified Muslims did not have jobs and students from poor Muslim families were unable to study at the Dhaka University. A vast section of the Muslim population was deprived of the benefits of education. This strained the relationship between Hindus and Muslims.

Although some elite Muslims after the Partition of Bengal demanded separate educational institutions in 1905, they failed to realize that separate schools did not receive proper financial aid from the government. The colonial government constantly decreased financial assistance, which increased competition in the field of education and employment. A few colonial officers, such as Sir Philip Hartog, wanted the government to help Muslims by increasing fellowships, but they recognized that it increased the financial burden of the government. Limited opportunities and lack of financial assistance from the government increased the animosity between the two communities. Bengali newspapers, such as the Soltan and Hanifi, in the second half of the 1920s blamed the colonial government for creating this rift between Hindus and Muslims. The absence of opportunities forced Muslims to demand reservation in government jobs, educational institutions, and legislative councils. Hindus opposed the system of reservation, and Muslims supported it. This conflict aggravated the communal situation of the province. Although the Khilafat and the non-cooperation movements united the two communities briefly, they were unable to provide a long-term solution to the problem.

\section{The Khilafat and the Non-cooperation Movements (1921-1923)}

The previous section shows that separate self-governing educational institutions intensified religious and communal differences. This section takes the story further, where I argue that the national movement along with education policies stimulated communal consciousness. After the war, the Bengali middle class was frustrated with the deteriorating living condition and low wages. Unemployment motivated them to join the national movement. This was also the period that saw the rise of Indian capitalists. The Marwari businessmen of Calcutta made considerable wealth, but the working class demanded an increase in wages and reduction in work hours. It was in this phase that Gandhi appeared in Indian politics. Gandhi's policy of ahimsa or non-violence and Satyagraha (passive resistance) satisfied moderates, pacified revolutionary terrorists, and the dominant section of the peasantry. Gandhi was able to organize a national struggle against foreign rule.

In organizing the Satyagraha, Gandhi made use of three political networks: pan-Islamic groups, home rule leagues, and the Satyagraha Sabha, which was started by him in Bombay. Gandhi maintained a close relation with the leaders of the Khalifat movement that was extremely popular in the 1920s. The Khilafat movement had three major demands: restoration of the Caliphate over Muslim sacred places; continuance of Muslim sovereignty in Arabia, Syria, Iraq, and Palestine; and the freedom to defend and practice their faith. Nawab Syed Nawab Ali Chowdhury (1920) and Maulana Shah Sufi Mohammad Abu Bakr (1920) in Islam Darshan and Banganoor indicated that it was important for the British government to retain the Caliphate and protect sacred Muslim places in order to maintain peace in India. The restoration of the Caliphate was important for the existence of the community.

The Central Khilafat Committee maintained a radical stand, and it was the group that started the non-cooperation movement at the Central Khilafat Conference in 1919. It organized the non-cooperation movement in four stages: boycott of titles, then civil services, followed by police and army, and finally, non-payment of taxes. The non-cooperation movement spread rapidly all over Bengal. In Bengal, the Dhaka Khilafat Committee organized 43 meetings that demanded swaraj (independence) and preached boycott. 
Al-Islam and Islam Darshan indicated that for Muslims, the non-cooperation movement had two goals: a solution to the Khilafat movement and freedom from colonial rule. Muslims wanted to restore the Caliphate but the government paid no attention to it. This forced a section of the Muslim community to join the non-cooperation movement. The Khilafat leaders urged for Hindu-Muslim unity and were willing to give up slaughter of cows. Also, the new leaders of the Bengal Provincial Muslim League wanted to develop the country, so they united with the Congress and the leaders of the Khilafat movement. Both the movements developed an anti-British attitude, boycotted British goods, opposed secular Western education, and wanted to establish schools that provided instruction in Arabic, Persian, and Bengali.

The idea to boycott British goods was also extended to educational institutions. In the 1920s, both the Indian National Congress and the All-India Muslim League boycotted government schools, councils, and courts. The boycott of educational institutions was more effective in Bengal, where approximately 20 headmasters or principals, resigned per month until April 1921. Bamford's (1925) confidential History of the Non-cooperation and Khilafat Movements showed that the movements had a huge influence on college education. As a result of the non-cooperation movement, arts colleges in Calcutta and government colleges in Hoogly, Krishnagar, and Chittagong were closed for several days. Between 1919 and 1922, students in government colleges declined by $15 \%$ and in aided colleges by $8 \%$. The number of pupils in high schools declined from 218,070 to 190,630 between 1919 and 1921. This decline was mainly because of the influence of the non-cooperation movement. A number of nationalist schools were established in different parts of India, such as the Jamia Millia Islamia in Aligarh. The famous Bengali poet Kaji Nazrul Islam in Dhumketur Pathe indicated that the colonial government only exploited the country and the method of petition would never bring about complete independence. The Choltan indicated that complete independence could be achieved through the Khilafat and the non-cooperation movements. This independence would benefit Muslims more than Hindus, and so it was important to boycott government schools, colleges, and jobs. However, these nationalist institutions dried up when the movements failed to achieve any considerable success.

Although no impact was felt on primary education, Berwick (1986) in his dissertation provided a detailed account of how students responded to the movement. Students of the Calcutta Madraasah organized a strike and started a national institution called the Madrassah Islamia. Students of the Chittagong College and Madrassah also boycotted classes, and those of the Jagannath College of East Bengal approached the principal to nationalize the college. However, Berwick (1986) argued that Presidency College students maintained their allegiance to the colonial government. For the British, this was a tribute to the British educators, and the Indian teachers of the college valued this connection. Unfortunately, students' movements were not independent of the Congress, and they failed to organize a stable campaign against colonial rule. Yet, Berwick (1986) considered the boycott of colleges and demonstrations organized by the students to be an important part of the non-cooperation movement in Eastern India.

At the same time, a few English-educated Muslims including Fazlul Huq, realized that cooperation with the government helped in securing political power. He, along with Nawab Habibullah opposed the non-cooperation movement. Huq (1991) opposed the idea of boycotting educational institutions, as it wasted public money collected from people as taxes. Maulvi Abdul Karim (1925) in his 1920s speech indicated that the boycott of British goods was never really the solution to the problem. It was important to use goods produced in India, but it was unnecessary to pass resolutions on the boycott of British goods and government jobs. He believed that Muslims had to cooperate with the government in order to receive further concessions. 
Although the movements failed, they successfully politicized Indian Muslims. As a result of this politicization, the Muslim members of the Bengal Legislative Council demanded provisions in the budget for the improvement of the community. They regretted that Calcutta University never had a Muslim vice-chancellor, and demanded proper representation in various departments of the government. Muslim leaders also expressed their grievances over the shortage of careers for young educated Muslims.

Newspapers and periodicals represented a variety of opinions. A section of the Muslim community supported the non-cooperation movement, while others believed that the movement hindered the progress of the community. Abdul Faruk and Mohammad Ismail Hussain Siraji (1924) argued that the non-cooperation movement, which started in Calcutta, had a disastrous influence on Muslims. Hindus did not quit government schools and jobs, whereas Muslim institutions went on a strike. The Shariat Islam indicated that Muslim students were most affected by the non-cooperation movement as they had to leave schools and colleges. Finally, an article published in Saogat indicated that the non-cooperation movement was organized to demand full independence, but India was still not ready for that.

The Khilafat and the non-cooperation movements were successful to a great extent in generating an anti-British attitude. They united Hindus and Muslims temporarily, and students boycotted government schools and colleges. But, the nationalist educational institutions did not always include students from the opposite community. There were a limited number of seats in these institutions. After the collapse of the non-cooperation movement in 1922, Hindu revivalist groups became powerful. Local Hindu organizations, such as the Hindu Sabha of Pabna, educated its followers of communal rights, such as the playing of music in religious procession. Muslim children in government and municipal schools were forced to sing the "Bande Mataram" as the national song. The Muslim community resented these activities. However, by this phase, the effects of the Lucknow Pact were also evident. The pact granted Muslims just 34\% of the elected seats in the Bengal Legislative Council. These grievances forced Jinnah to criticize the Congress and Gandhi for establishing a Hindu Raj in the country. Unfortunately, the colonial government was unable to develop a stable education policy for Muslims beyond the establishment of separate schools. Colonialism along with Hindu imperialism forced Muslims to strengthen their demand for reservation of seats in government educational institutions. Finally, the Bengal Pact of 1923 made the last attempt to unite the two communities.

\section{The Crucial Period (1923-1930)}

\section{The Bengal Pact of 1923 and Its Influence on the Progress of Muslim Education (1923-1927)}

After the collapse of the non-cooperation movement, the national movement underwent several shifts between 1922 and 1927. Gandhi's promise of swaraj in the 1920s failed, and the rift between the Swarajists (Indian leaders who opposed Gandhi after the collapse of the non-cooperation movement) and no-changers (supporters of Gandhi) increased. This decrease in unity led to communal riots. There was a split in the Congress at the Gaya session in 1922 over whether the Congress should participate in the council elections. The Congress rejected the proposal to contest the Bengal Council elections, but Chittaranjan (C.R.) Das and Motilal Nehru set up the Swaraj Party in 1923 and decided to contest the elections. They won the elections in 1923 with 47 out of the 85 general Hindu and Muslim seats, including the 21 Muslim constituencies. On the basis of this victory, Das proposed a new pact between Hindus and Muslims. They made an effort to unite the two communities and promised Muslims 55\% reservation in the administrative posts after attaining swaraj. Both Das and M. Nehru assumed that unity between the two communities could be reached, if Muslims gave up cow 
killings and Hindus stopped playing music in front of mosques.

The Bengal Hindu Muslim Pact also known as the C.R. Das Pact, assured elite Muslims administrative jobs and political participation. After winning the elections, the swarajists wanted to form a responsible government. Das introduced a system of free primary education, medical relief, and proper sanitation for people living in slums. The Swaraj Party awarded grants to hospitals and schools, and Das attempted to improve the living condition of the middle class and the poor by providing the benefits of self-government, within the limitations of colonial rule. The party also established links with businessmen for financial support. Finally, Das included Muslim councilors from separate electorates, in order to build a nationalist organization, which incorporated diverse and antagonistic elements of Bengal politics.

Unfortunately, the success of the pact was short lived, as they were unable to protect 80 Indians who were detained for allegedly being terrorists. Das was forced to cooperate with the government in 1925 for the release of the prisoners. However, immediately after Das's death, the party was divided into several factions, and his followers did not recognize the importance of Muslim support in the province. For example, the Muslim councilors of the Swaraj Party walked out of the Calcutta Corporation over the "pir-burial" issue and the resignation of the Muslim Deputy Mayor H.S. Suhrawardy. The pact failed to satisfy the Marwari businessmen, on whom the swarajists depended for financial support. The privileged Hindus were afraid of losing their positions to Muslims. The pact was actually a threat to the advantages enjoyed by the Hindu landed, commercial, and professional classes.

The Bengal Pact did not oppose Hindu communalism or the activities of the Hindu Mahasabha. Movements, such as the Shuddhi and Sangathan, started by the Hindu Mahasabha in 1923 created a feeling of distrust among Muslims. Dainik Basumati and Ananda Bazaar Patrika blamed Muslims for their backwardness. They criticized maulvis for inciting Muslims against Hindus and accused Muslim gangs of abducting Hindu women and killing Swami Sradhananda. This was mainly because Muslims opposed the Hindu revivalist movements started by the Swami. Similarly, Dainik Soltan (1926), argued that Hindus opposed the development of the Muslim community. The Congress was a Hindu organization, and the demands of the Muslim community were never respected. The Calcutta University did not hire Muslim professors except for Arabic and Persian faculty members, and the government did not spend enough money on Muslim education. Some colleges, such as the Rajshahi College, did not even have Arabic and Persian teachers. The pact promoted unity at the elite level but never really solved the Hindu-Muslim problem.

After the pact was abrogated in 1926, a volatile political situation existed in Bengal. Political leaders and conservative groups, such as Jamiat-i-Ulema and Tanzeem-ul-Mussalman, promoted communal hatred. The activities of the Cow Protection League decreased the sale of cows in Calcutta. This increased Muslim resentment. At the same time, educated Muslims struggled for jobs and seats in the Bengal Legislative Council. The social crisis and the growing communal tension forced Muslims to demand reservation in educational institutions and separate schools.

The report of the Director of Public Instruction for 1925 and 1926 showed that, in 1926, the presidency had a total of 467 madrassahs with 42,527 students. Muslims wanted reservation in government and aided schools, and also stipends and free studentships. The Islamia College was established for Muslims in 1926. There were two Islamic intermediate colleges in the province: one at Dhaka and the other at Serajganj. They subsidized fees and maintained an Islamic culture and tradition. These institutions provided instruction in Mathematics, Physics, and Chemistry, and also appointed teachers who were qualified to teach English, History, 
and political economy.

Despite these facilities, the Muslim community did not make an overwhelming improvement in education. In 1926, Calcutta had 429 primary schools with 28,035 students, of which 17,112 were Hindus and 10,562 were Muslims. Muslim students were hardly visible in higher education. Muslims made up only $18 \%$ of the total teaching staff in non-governmental schools and just $24 \%$ in government schools. Table 1 shows that although the number of Muslim teachers and inspecting officers increased in Bengal after the Montagu-Chelmsford reforms, it was insufficient in comparison to the total population.

Table 1

Percentage of Muslims Employed in the Different Districts of Bengal

\begin{tabular}{lclll}
\hline & $\begin{array}{l}\text { No. of Muslims holding } \\
\text { appointments as teachers }\end{array}$ & $\begin{array}{l}\text { No. of Muslims holding } \\
\text { appointments as inspecting } \\
\text { offices }\end{array}$ & $\begin{array}{l}\text { \% of teaching appointments } \\
\text { held by Muslims }\end{array}$ & $\begin{array}{l}\text { \% inspecting } \\
\text { appointments held by } \\
\text { Muslims }\end{array}$ \\
\hline Presidency & 31 & 29 & 32.6 & 50.0 \\
Burdwan & 10 & 16 & 17.8 & 22.2 \\
Dhaka & 27 & 39 & 20.7 & 46.4 \\
Rajshahi & 29 & 28 & 28.15 & 41.8 \\
Chittagong & 6 & 30 & 14.3 & 58.8 \\
Total & 103 & 142 & 22.71 (Average) & 43.84 (Average) \\
\hline
\end{tabular}

Note. Source: Report of the Director of Public Instruction in Bengal 1925-26 September 1927, CSA, Education. File No: Edn 8 R-1 (3), Proceedings No: 8.

Primary education was necessary for poor Muslim peasants, and they mostly preferred madrassahs and maktabs. Muslim organizations, such as the Khulna District Muhammadan Association and the Faridpur Anjuman-i-Islamia, expressed their discontent over the school curriculum and the curriculum adopted by the Dhaka University. The curricula did not suit the needs of the prospective Muslim students from East Bengal, and most of them could not pay the fees to attend these schools. These organizations demanded the implementation of the Bengal Rural Primary Education Bill in order to improve mass education. The abandonment of the non-cooperation movement followed by the failure of the Bengal Pact forced Hindus and Muslims to seek different political paths for the advancement of their respective communities. Many newspapers, such as Kandi Bandhav and Janavani in 1927, urged Hindus and Muslims to unite. Kaji Nazrul Islam (1926) in the article "Hindu-Muslim" suggested that riots did not produce any constructive results. "God does not want people to fight”. Muslim maulvis and Hindu pundits incited people against each other. Sadly enough, the political situation and the educational reforms only multiplied the grievances of the two communities.

Education policies overlooked the needs of the masses, and grievances increased over inadequate education facilities, delay in the introduction of the Rural Primary Education Bill, and communalism. Separate educational institutions did not improve the quality of education. A section of the Muslim population could only afford these schools, and the education curriculum within these separate schools was unsuitable for securing government jobs. After a point, even the colonial government found it difficult to support these separate educational institutions. This systematic change in education policies widened communal divisions. Finally, the Bengal Pact attempted to unite the two communities through several reforms. It was probably the last phase of Hindu-Muslim unity. After the failure of the pact, there were violent riots all over the province. In this volatile situation, Muslim members of the Bengal Legislature demanded the implementation of the Bengal 
Rural Primary Education Bill of 1930. The next section will evaluate the debates over the implementation of the bill.

\section{The Bengal Rural Primary Education Bill of 1930 (1927-1930)}

The period between 1927 and 1930 saw contradictory and complex political developments. The all-white Simon Commission announced on November 8, 1927, had a drastic influence on the Indian society. It considered Indians incapable of developing a constitution for themselves. Politicians, such as Tej Bahadur Sapru and Mohammad Ali Jinnah, united with the Congress to formulate the Dominion Status Constitution. At the same time, the movement to boycott the Simon Commission demanded complete independence and initiated a variety of socio-economic changes.

The commission addressed some of the problems of higher education. It suggested that the province did not have proper colleges, and that students from villages found it difficult to continue their education in the city. The commission indicated that in order to improve the condition of higher education, universities should only admit a few students and provide them with extensive opportunities for research. It praised the Dhaka University for uplifting the status of the Muslim community and recommended the establishment of boards for the improvement of Muslim education. Muslims, who supported the commission, refused to give up separate electorates and believed that the commission recognized the problems of the Muslim community and sincerely wanted to improve their social status.

Following the commission, there were two major developments. First, Motilal Nehru's report could not bring the two communities together as it gave major concessions to the Hindu Mahasabha. Second, a section of the Muslim League were unwilling to give up separate electorates and boycott the Simon Commission. They feared that Hindu domination would hinder the progress of the community. Even the Muslim Graduate Association feared that after colonial rule they would be dominated by Hindus. Hence, they decided to cooperate with the Simon Commission. Newspapers such as the Muslim Darpan campaigned for separate electorates and educational institutions, and insisted that Muslims of Bengal should cooperate with the Simon Commission in order to improve their economic situation.

Throughout 1928 and 1929, a convoluted relationship existed between Hindus and Muslims. There were riots all over the province, and historians have argued that the Bengal Rural Primary Education Bill of 1930 was one of the pressing needs of the time. The budget of the Government of Bengal for 1925 and 1926 showed that the total income of the government was 11,000,000 rupees, of which only three crore were spent on developing the province. Karim (1925) indicated that there was no scope for correlating education with employment. The existing system of primary education did not suit the needs of people. He insisted that primary education had to be related to agriculture and village art and crafts. Similarly, Khan Sahib Abdus Sattar argued that most village primary schools had just one teacher appointed by the district board, and opened once or twice a month. Karim and Sattar highlighted the need for a stable primary education system.

Huge debates continued in the Bengal Legislature between Hindus and Muslims over the Bengal Rural Primary Education Bill of 1930. Educated Hindus such as Babu Joginchandra Chakravarti and Babu Bejoy Krishna Ghose, argued that the money allocated by the government for education was insufficient. A grant of 200,000 rupees to the Calcutta University and 392,000 rupees for education was not enough for educating the entire population of Bengal. Kumar Shib Shekhareswar Roy and Narendra Kumar Basu (1931) opposed the bill. They indicated that the bill imposed heavy taxes on Hindus. The Hindu zamindars (landlords) had to pay 25\% 
of their total revenue, and the colonial government ignored the feelings of Hindus.

However, ministers, such as Maulvi Wahed Hussain and Khan Bahadur Maulvi Syed Muqbul Khan, demanded free and compulsory education for Muslims. They insisted that diarchy was unsuitable for the needs of the country. There was no cooperation between the government and the elected ministers. Azizul Huque argued that even after Muslim willingness to pay the extra taxes, the colonial government deferred the introduction of the bill. The members of the Bengal Legislature were involved in a heated discussion over the implementation of the bill. Muslims faced tough opposition from the Hindu leaders. The debate over the bill alienated many Muslims, as compulsory primary education was needed to improve the educational condition of the community in rural areas. However, Hindu and Muslim leaders were unable to come to a unanimous decision over the Rural Primary Education Bill.

The bill was also criticized by the colonial educationist, Sir Philip Hartog. Hartog (1929) suggested that compulsory primary education was good in theory but not in practice. The rapid expansion of primary education would produce disastrous results for India and also Bengal. The number of primary schools increased, but the method of instruction was unsystematic and uneconomic. Secondary and higher education suffered. Schools had inefficient teachers and private tutoring was almost universal. In Bengal, the Government of India provided financial assistance to just 898 recognized schools, while the unaided institutions struggled for financial aid.

Finally, despite several arguments and criticisms, the bill was made into a law in 1930. The law was first introduced in Mymensingh, Chittagong, Pabna, Dinajpur, Noakhali, Birbhum, and Bogra. A committee of 27 members was set up to inspect the proper implementation of primary education in these districts. The committee recommended a standard curriculum for improving primary education. The Bengal Primary Education Fund was also established to monitor the expenditure of the committee on primary education. The bill remained one of those incidents that further widened the distance between the two communities, as Hindus opposed the bill and Muslims to a great extent supported it.

Although the bill was implemented, it was severely criticized by both Hindu and Muslim members of the legislature. For example, Abdul Karim indicated that the Primary Education Act of 1930 did not develop a proper curriculum that improved primary education. The course of study did not meet the requirements of Muslim students. Maktabs were not considered as primary schools, and this discouraged poor Muslims from sending their children to schools. The government spent a lot of money on administration, but inadequate financial aid was allocated for primary education. There was no major improvement in the condition of primary education. The literacy rate improved from 3\% in 1881 to $8 \%$ in 1931. According to the census of 1921, only $9.5 \%$ of the total Muslim male population was educated. It increased to $9.8 \%$ in 1931 . This increase of $0.3 \%$ provided a very gloomy picture of the state of Muslim education. In 1931, the total Muslim population of Bengal was 29,497,624, out of which only 1,572,607 were literate. The Muslim community believed that it was the duty of the government to provide all the necessary facilities for the improvement of Muslim education. Leaders, such as Nur Ahmed, acknowledged government's contribution, but suggested that it was inadequate in comparison to the total Muslim population. There was a huge demand for government assistance to improve Muslim education. The first two sections analyze the condition of Muslim education during the 1920s. Lack of resources and absence of financial assistance were the two major problems throughout the early decades of the 20th century. Even after the transfer of the Education Department to the elected ministers, the government did not assign enough grants to the department. Despite the introduction of the reformed madrassah system and 
establishment of separate schools, Muslims progressed very little in comparison to Hindus. By 1932, arts colleges in Bengal had only 13\% of the total Muslim male population and $1 \%$ of the total Muslim female population of the province. There were hardly any Muslim girls in medical, engineering, and commercial schools. However, the political situation of the province constantly fueled the idea that Muslim dreams and aspirations were different from those of Hindus. Historians have argued that during the 1920s and 1930s, Muslims were unsure of their political position, but grievances over jobs, representation, and education strengthened a sense of separate identity. The colonial government designed policies that did not prove advantageous for any of the communities, and the two communities in an attempt to secure further privileges for themselves, were always at conflict with each other.

\section{The Increase in Animosity Between Hindus and Muslims: From the Civil Disobedience Movements to the India Act of 1935 (1930-1935)}

This section shows how the animosity between Hindus and Muslims increased over education policies formulated between the Civil Disobedience movements (1930-1932) and the India Act of 1935. Towards the end of the second decade of the 20th century, Gandhi encouraged the boycott of British goods. However, he rejected Jawaharlal Nehru's independence proposal at the Madras session of the Congress in 1927. At the Calcutta session the next year, Gandhi accepted the idea of Dominion Status proposed by Jawaharlal Nehru. The Congress was free to go in for Civil Disobedience and Purna Swaraj (complete independence) if British had failed to grant Dominion Status by 1929. However, the Congress rejected Lord Irwin's offer and adopted the policy of complete independence. Gandhi on January 26, 1930, launched the first Civil Disobedience Movement.

The first Civil Disobedience Movement had a major impact on Indian society. The imports fell from 26,000,000 pounds in 1929 to 40,000,000 pounds in 1930. Indians boycotted the legislative council elections of 1930. However, the Hindu-Muslim problem remained unsolved. Muslim leaders, such as Aga Khan, Muhammad Shafi, and Muhammad Ali Jinnah, encouraged Muslims to campaign against the movement launched by Gandhi. Mohammad Ali Jinnah urged Muslims to oppose the Congress, which was primarily a Hindu organization. Hence, Muslims were encouraged to stay away from the movement. There was hardly any unity between Hindus and Muslims during this period.

Following the first and second civil disobedience movements, the Communal Award of 1932 was an inevitable outcome of the Hindu-Muslim conflict. In the Bengal Council, Hindus had 46 and Muslims had 39 seats. The situation immediately changed after the award, and Muslims held majority of the seats. Muslims enjoyed a stronger position, and the award forced congressmen to join Hindu communal leaders. Many Muslim congressmen left the Congress, considering it to be a Hindu institution. Muslims feared that the leaders of the country wanted to establish Hindu rule, which was unacceptable for the Muslim community. Hindus denounced the award, whereas Muslims united in its defense. Newspapers, such as the Watan, argued that stubbornness on the part of the Congress and the imprudent attitude of the Mahasabha were important reasons for the conflict between Hindus and Muslims.

By 1932, a difficult social and political situation existed. The colonial government continued to follow strict financial policies and wanted to preserve separate electorates in order to pacify the Muslim community. At the same time, the civil disobedience movements failed due to lack of proper political participation and leadership. Even Gandhi was unable to solve the Hindu-Muslim issue. There were riots in Dhaka, Kishorganj, 
and Chittagong. Hindus and Sikhs requested the government to revise the award. Historians have argued that the communal award was used by the government to exploit the differences between the two communities. It rejected the demands of the Indians on political issues related to the transfer of power from the British Parliament to the Indian people.

In this social milieu, the Muslim leaders wanted the government to increase grants for Muslim education. The government responded to this demand by appointing a committee in 1934 that supervised the progress of Muslim education. The report of the committee indicated that in 1932 only 13\% of the total Muslim population studied in arts colleges, as compared to $14 \%$ in 1927. Fewer Muslims were noticed in commercial, engineering, and medical schools. The number of Muslim students increased in primary schools but it never improved beyond the lowest stage. For example, between 1931 and 1932, 35 out of 100 Hindu boys reached the 3rd and 4th grades, whereas 14 out of 100 Muslim boys reached that level. A large number of Muslim boys dropped out of schools before completing the primary courses and relapsed into illiteracy. There were rarely any Muslim students in engineering, medical, and industrial schools. The annual report of the Dhaka University for the years 1932 and 1933 showed a decrease in the number of students pursuing degrees in arts and sciences. The situation slightly improved between 1933 and 1934, but the overall condition of Muslim students remained the same. The government continued to decrease funds for Muslim education and students dropped out of secondary and primary schools. Muslim students failed to avail the benefits of university education. The committee suggested that Muslims felt that the colonial government did not help them adequately, and the education system was unaffordable for poor Muslims. The committee constantly emphasized that a definite number of seats had to be reserved for Muslims in schools, colleges, ministry, and administration. They recommended the appointment of a Muslim as the head of the Islamic Studies Department at the Dhaka University and 50\% reservation on all selection committees. Muslims had to be appointed as teachers and the number of free studentships for Muslim students had to be fixed at $20 \%$ of the total school population. Finally, they wanted maktabs to be considered as primary and not segregated schools, which included both Muslims and non-Muslims, and provided religious and secular instruction.

Following the recommendations of the committee, the Muslim members of the Bengal Legislature passed a resolution that Muslim inspectors had to be appointed for the improvement of Muslim education in all divisions of the presidency. Recruitments had to be made on the basis of the population strength. Despite several resolutions, qualified Muslims were rarely appointed to various positions. Governing bodies of colleges were reluctant to employ qualified Muslims. There was no dearth of qualified Muslims, but laws were never properly implemented to suit the needs of the community.

Evidence indicates that time and again the Bengal Education Department suffered from financial crises. Strict economic policies affected the overall progress of the community. Even after the establishment of separate schools, there was no financial support from the government. At the same time, both Hindu and Muslim leaders used sectional slogans to gather support. Hindus opposed the appointment of maulvis in high schools, and Muslims considered the Congress to be a Hindu organization. The Congress propaganda of a free India did not necessarily mean secular India, and mullahs or Muslim clerics divided India along religious lines. Grievances over limited financial support and jobs strengthened the demand for separate educational institutions.

Students also expressed their concerns over the growing communal tension between the two communities. Muslim and Hindu students wanted to unite the two communities. Aziz-ud-din Ahmed and Matindra Chandra 
Bardhan (1925) in the articles "Mahomedan Education in Bengal" and "Indian Nationalism" argued that Muslims failed to progress because they were unable to adjust to the Western system of education. Education policies preferred Hindus over Muslims. The community did not receive proper help from the government. Both Ahmed and Bardhan (1925) opposed the idea of separate schools for Muslims. Separate schools did not bring about unity between the two communities. There were economic, linguistic, and political differences, but communalism was the main problem. It was essential to have schools that included both Hindus and Muslims. The discriminatory approach of the government and the failure to adjust to the liberal European system of education were the major reasons for Muslim backwardness. The educational and economic disparities between the two communities strengthened communal consciousness. Colonial education policies created a situation that forced the two communities to realize that their goals and aspirations were different. These differences created a rift between Hindus and Muslims and were crucial for the rise of communal tension.

After the failure of the civil disobedience movements, the Congress with the support of the Indian capitalists, wanted to contest the legislative assembly elections in several provinces. This period also saw the rise of the Communist Party, which strongly opposed the Indian capitalists. In these circumstances, Hindu and Muslim groups were unable to reach a unified vision for free India. The political leaders demanded greater benefits and revivalist groups gave communal color to political issues, such as the slaughter of cows and playing of music in front of mosques. Dainik Basumati, Amrita Bazaar Patrika, and Ananda Bazaar Patrika blamed Muslims for their backwardness. Similarly, Dainik Soltan (1927) and Choltan (1923) argued that Hindus opposed the development of the Muslim community. This animosity created problems for Muslim education. Muslims demanded reservation of seats in educational institutions, government jobs, and legislative assemblies. They considered these concessions as part of a method to improve their position. The policies introduced by the government did not give Muslims proper opportunity for advancement. Muslim leaders constantly demanded greater funds, but neither the government nor the elected ministers properly implemented education policies to benefit the Muslim community.

The political turmoil and debates over reservation of seats and separate educational institutions continued till the end of colonial rule. Fazlul Huq (1996) urged Muslims to end the communal strife and jealousy, as India was on the threshold of constitutional changes. However, Jinnah by the middle of the 1930s was extremely vocal in his demand for the creation of Pakistan. He wanted to safeguard the rights of Muslim minorities from the Hindu Mahasabha, Arya Samajists, and the Congress. The colonial government at the same time introduced the India Act of 1935 that replaced diarchy in the provinces with responsible governments. But, the colonial governors still retained discretionary powers. Limited opportunities offered by the colonial state restricted the prosperity and progress of the Bengali intelligentsia.

\section{Conclusion}

This paper provides a detailed overview of the condition of education during the crucial years of colonial rule. Several primary and secondary sources indicate that even after the introduction of reforms, such as separate educational institutions and electorates, there was never any significant improvement in the condition of Muslim education. For example, the Dhaka University was established to improve Muslim education in East Bengal, but it suffered from financial crises. The residential system of education imposed by the colonial rulers deprived the masses of education, and brought about uneven development in society. Muslims did not progress as expected, and their illiteracy was used by Hindu and Muslim leaders to mobilize the masses against each 
other. Hindus were unwilling to give up their dominant position, and Muslims were afraid of Hindu domination after colonial rule. The national movement directed against colonial rule impoverished the masses. In such a condition, Muslims supported the idea of separate electorates and educational institutions. However, some Muslims preferred separate schools, as it allowed them to maintain their Islamic culture and tradition. The colonial government believed that separate educational institutions were the best solution to the communal problem. Unfortunately, separate schools for Muslims only intensified the communal division. It forced Muslims to think that their position in the society, could only improve if they attended these schools. It can be argued that colonialism and the national movement played an important role in the emergence of communalism, and education was the sector that allowed these differences to be further radicalized.

The debates of the Bengal Legislature and newspaper reports severely criticized the colonial government for reducing grants. Both Hindu and Muslim leaders demanded privileges and benefits for their communities. Newspapers often accused each other of spreading communal hatred. Unfortunately, most of the debates and newspaper reports overlooked the problems associated with the implementation of the reforms. The local agencies responsible for implementing the reforms discriminated against Muslims. There was a huge gap between formulation and implementation of the reforms. The government introduced several policies but never paid much attention as to whether the policies really improved the position of the masses.

Policies introduced by the colonial government with the support of the Indian bureaucracy only alienated Muslims against Hindus, as not enough money was allocated for the purpose of education. Education was the domain that allowed these grievances to be politicized. Educational reforms introduced by the colonial government did not suit the needs of the province. Initially, with the beginning of colonial rule, Muslims stayed away from Western education but later on endorsed it to improve their social and economic status. However, to a great extent, they were unable to adjust to the secular Western system of learning. This form of education was expensive and always at crossroads with their religious views. A vast majority of the Muslim intelligentsia who believed that colonial education policies would improve their situation, turned against colonial rule, as the policies failed to achieve their goals. Grievances over educational reforms and communalism strengthened educational separateness.

\section{References}

Ahmad, M. M. (1935). Present day problems of Indian education: With special reference to Muslim education. Bombay: B.N.Kapadia at the Fine Art Press.

Al-Masum, M. (2008). Abdullah, British amole Banglar Muslim Sikha: Samasya o Prashar. Dhaka: Bangla Academy Press.

Berwick, J (1986). Chatrasamaj: The social and political significance of the student community in Bengal 1870-1922 (Doctorial dissertation, University of Sydney).

Chandiprasad, S. (1991) The Bengali Muslims: A study in their politicization 1912-1929. Calcutta: K.P.Bagchi \& Company.

Chatterjee, J. (1995). Bengal divided: Hindu communalism and partition, 1932-1947. New Delhi: Cambridge University Press.

Collection of Sir Philip Hartog, Dacca University Journals, February 1925, BL, MSS EUR E221/136.

Editorial. (1920). Banganoor, Bangali Musalman Sampadito Samoyik Patro.

Editorial. (1923). Choltan, Bangali Musalman Sampadito Samoyik Patro.

Editorial. (1924). Islam Darshan, Bangali Musalman Sampadito Samoyik Patro.

Editorial. (1927). Dainik Basumati, Report on Newspapers and Periodicals in Bengal.

Hardy, p. (1983). The Muslims of British India. Cambridge: Cambridge University Press.

Hasan, M. (Ed.). (1981). Communal and pan-Islamic trends in colonial India. New Delhi: Manohar Publications.

Huque, M. A. (1917). History and problems of Moslem education in Bengal. Calcutta: Thacker Spink \& Co..

Kabir, H. (1944). Muslim politics 1906 -1942. Calcutta: Gupta Rahman \& Gupta. 
Kaji Nazrul Islam. (1926). Hindu-Muslim. Ganabani, Bangali Musalman Sampadito Samoyik Patro.

Karim, A. (1925). Presidential address delivered at the session of the all India Muslim League. Calcutta: Karim Bux Brothers Printers.

Kaura, U. (1977). Muslims and Indian nationalism: The emergence of the demand for India's partition 1928-1940. New Delhi: Manohar Book Service.

Maulana Shah Sufi Mohammad Abu Bakr. (1920). Khilafat Proshongo. Islam Darshan, Bangali Musalman Sampadito Samoyik Patro.

Proceedings of the Government of Bengal, February1915, CSA, Education. File No: 1-M/6 -12, Proceedings No: 134-135.

Rashid, O. H. (1987). The foreshadowing of Bangladesh: Bengal Muslim League and Muslim politics 1936-1947. Dhaka: Asiatic Society of Bangladesh.

Ray, R. (1979). Urban roots of Indian nationalism: Pressure groups and conflict of interests in Calcutta city politics, $1875-1939$. New Delhi: Vikas Publishing House Pvt Ltd..

Rules for Students of the Jagawnath Hall, Dacca University, 1928, BL, MSS EUR E221/120.

Sarkar, C. (1991). The Bengali Muslims: A study in their politicization 1912-1929. Calcutta: K.P.Bagchi \& Company.

Sarkar, S. (1983).Modern India 1885-1947. New Delhi: Macmillan India Ltd..

Shah, M. (1996). In search of an identity: Bengali Muslims 1880-1940. Calcutta: K.P.Bagchi \& Company.

Sir Philip Hartog: Papers as Chairman of Education Committee of Indian Statutory Commission, BL MSS EUR 221/58.

Sir Philip Hartog: Papers as Chairman of Education Committee of Indian Statutory Commission 1928-1929, BL, MSS EUR 221/58

Suchetana, C. (2004). Muzaffar Ahmad, Calcutta, and socialist politics, 1913-1929 (Doctorial dissertation, University of London). Sumit, S. (1983). Modern India 1885-1947. New Delhi: Macmillan India Ltd..

The Bengal Legislative Assembly Council. (1931). The Bengal (Rural) Primary Education Bill, 1930. 